\title{
PENGGUNAAN BAHASA SLANG PADA KOMUNITAS WARIA DI KOTA SURABAYA (KAJIANLINGUISTIK)
}

\author{
Alfian Endy Nugraha, Taufik Nurhadi \\ (Pendidikan Bahasa dan Sastra Indonesia, Fakultas Keguruan dan Ilmu Pendidikan, \\ Universitas PGRI Adi BuanaSurabaya) \\ Alfianendynugraha8@gmail.com, taufiknurhadi70@gmail.com
}

\begin{abstract}
ABSTRAK
Latar belakang penelitian ini adalah kenyataan bahwa bahasa selain sebagai alat komunikasi, bahasa juga sebagai saluran inspirasi. Dari waktu ke waktu bahasa sudah menempati suatu peradaban dimana bahasa bukan hanya bahasa resmi, tetapi lebih dari itu bahasa sudah mulai mengalami pergeseran. Tujuan analisis bahasa gaul adalah untuk mengetahui perubahan kosakata bahasa gaul di komunitas transgender. Seperti contoh bahasa gaul yang mengubah kosakata bahasa Indonesia sebagian atau seluruhnya. Objek penelitian ini adalah kosakata yang digunakan oleh komunitas waria di kota Surabaya. Metode pemilihan data dilakukan dengan tiga cara yaitu penyadapan teknik dasar dan teknik lanjutan (SLC) dan catatan teknis. Teknik analisis menggunakan metode agih. Analisis data didasarkan pada teori linguistik. Teknik analisis menggunakan metode agih. Analisis data didasarkan pada teori linguistik. Berdasarkan hasil penelitian dapat disimpulkan bahwa terdapat beberapa perubahan kosakata bahasa dengan bahasa gaul bahasa Indonesia. Diantaranya, (1) Penggantian (2) Penambahan (3) Penyisipan (4) Penghilangan (5) Pengulangan (6) Perubahan total.
\end{abstract}

Kata kunci: Gaul, Waria, Linguistik

\section{PENDAHULUAN}

Eksistensi bahasa dalam hidup dan kehidupan di dunia memegang peranan penting, sebab bahasa dan kehidupan sosial adalah hal yang tidak mungkin dipisahkan dalam kehidupan masyarakat, serta interaksi sosial yang tidak akan pernah dapat tercapai tanpa adanya bahasa sebagai alat komunikasi. Bahasa merupakan salah satu wujud kegiatan, dalam kehidupan ini. Jika tidak disertai dengan bahasa yang merupakan sarana komunikasi antar individu, kelompok, dan antar bangsa maka kehidupan akan statis dan tidak ada interaksi sosial dalam masyarakat. Bahasa menurut Samsuri(1978:16) adalah segala sesuatu yang merupakan isi pikiran, perasaan dan menyatakan wejangan, serta harapan terhadap Allah Swt. Segala ucapan yangmanusia lakukan, baik sendiri maupun berkumpul dengan teman pasti menggunakan bahasa. Hal ini terlihat pada kegiatan sehari-hari dan pada kegiatan khusus misalnya pada suatu tempatkeramaian, jelas di tengah hiruk pikuknya keramaian tersebut tak hentihentinya menggunakan bahasa.

Demikian juga halnya yang terjadi pada seseorang yang lagi menyendiri, meskipun tidak mempunyai teman untuk berdialog atau berbicara, akan tetapi apabila orang tersebut sadar atau tidak sadar 
pasti menggunakan bahasa sebagai alat untuk merangsang hasil pikiran dan khayalan. Sudah dimaklumi bahwa fungsi umum yang paling utama bahasa adalah sebagai alat komunikasi yang paling sempurna. Hampir semua aktivitas bahasa sangat dibutuhkan dalam berbagai situasi komunikasi. Oleh sebab itu, bahasa demikian pentingnya pada masalah yang berhubungan dengan bahasa itu sendiri. Perhatian yang dicurahkan pada masalah bahasa tidak saja di kalangan lingkungan, akan tetapi di kalangan ahli dalam bidang lain seperti psikologi, antropologi, dan sosiologi. Bahasa sebagai alat komunikasi juga berkaitan dengan asas sosial dari masyarakat itu sendiri, semua unsur dimasukkan untuk mendapatkan tanggapan, baik berupa tutur, maupun yang berhak berbahasa atau tindakan. Uraian di atas dapat disimpulkan bahwa bahasa merupakansalah satu wujud kegiatan dalam kehidupan sosial. Penulis bermaksud mengadakan penelitian tentang bahasa yang kini umum dipakai oleh kelompok waria.

Dalam kehidupan sosial,selalu ada kelompok tertentu yang mempunyai bahasa tertentu yang merupakan lambing identitas kelompoknya, yang ditandai dengan kekhasan perilaku dan pemakaian bahasa. Kekhasan inilah yang membedakan dari kelompok lain. Kekhasan ini hanya dipahami oleh mereka dalam kegiatan yang mereka lakukan bersama.

Salah satunya adalah yang digunakan oleh komunitas banci. Bahasa yang digunakan oleh komunitas banci sangat beragam. Salah satu ragam bahasa yang digunakan adalah dalam bentuk jargon. Chaer dan Leonie Agustina (1995:89) mengartikan jargon sebagai variasi sosial yang digunakan secara terbatas olehkelompok-kelompok sosial tertentu. Jargon berbentuk ungkapanungkapan yang seringkali tidak dapat dipahami oleh masyarakat umum atau masyarakat di luar kelompoknya. Namun, ungkapan tersebut tidak bersifat rahasia. Banci dalam Kamus Besar Bahasa Indonesia (1990:74) adalah 'laki-laki yang bertingkah laku dan berpakaian seperti perempuan'. Dalam penelitian ini, banci yang dimaksud adalah laki-laki yang bertingkah laku seperti perempuan, mulai dari cara berbicara, cara berjalan, dan cara bersosialisasi dengan lingkungan seperti perempuan. Banci atau waria, menurut pakar kesehatan masyarakat dan pemerhati waria Dr. Mamato Gultom, adalah subkomunitas dari manusia normal. Bukan sebuah gejala psikologi, tetapi suatu yang biologis. Perilaku dan dandanan mereka yang menyerupai wanita, terlihat ganjil jika mengingat status mereka sebagai lelaki, gagah gemulai, cantik berotot, tentu dengan gaya bicara yang dibuat segenit mungkin. Kaum ini berada pada wilayah transgender. Perempuan yang terperang kapdalam tubuh lelaki (http://www.KotaSantri.com). Waria merupakan sekelompok bagian dari masyarakat yang mempunyai komunitas tersendiri. Sesama waria dalam menggunakan bahasa tertentu dilihat dari situasi tertentu yang disebut ragam bahasa.

Pada dasarnya penelitian bahasa waria sudah banyak yang meneliti, hal ini penelusuran pada google scholar. Penelitian yang akan 
dikemukakan, yang pertama penulis Iis Khomariah yang berjudul "Jargon Yang Digunakan Komunitas Banci Salon Di KotaPadang, Sumatera Barat (Tinjauan sosiolinguistik) Penulis memilih salon sebagai tempat pencarian data karena salon merupakan salah satu tempat yang dipilih oleh komunitas banci untuk menghabiskan waktu dan berkumpul bersama teman-teman satu kelompoknya. Komunitas banci memilih berlama-lama di salon karena komunitas ini dikenal dengan komunitas yang sangat memperhatikan penampilan dan kecantikan fisik, bahkan ada sebagian dari komunitas ini yang mempunyai salon sendiri. Untuk itu, salon merupakan tempat yang akurat untuk memperoleh data dalam melakukan penelitian jargon yang digunakan oleh komunitas banci. Berdasarkan penelitian, bahasa yang digunakan oleh komunitas banci cenderung menggunakan kosakata yang panjang, lucu, dan berkesan berbeda dari bahasa yang dipakai pada umumnya. Namun demikian, kosakata tersebut tetap difahami oleh kelompok mereka. Kosakata yang mereka pakai pada umumnya mengacu pada isu yang sedang aktual. Mereka dikenal senang ngerumpi, membahas hal-hal yang sedang terjadi meski dengan kaca mata pandangan mereka yang umunya memiliki sifat hangat, ramah, akrab dan lucu. Bahasa mereka mencerminkan sebagian sifat-sifat mereka yang peka karena pada dasarnya mereka orang yang kreatif. Bahasa mereka mewakili bentukbentuk kreativitas tersebut. Berikut adalah contoh tuturan yang menggandung jargon yang digunakan oleh komunitas banci:

Pada peristiwa tutur tersebut, terdapat dua buah jargon yang digunakan oleh komunitas banci yaitu malelong dan tinta. Penutur (X) menanyakan apakah mitra tutur (Y) akan pergi malelong? Lalu mitra tutur (Y) menjawab tinta, karena alasan malas. Jargon malelong dan tinta adalah bahasa khas dari komunitas banci. Kata malelong pada peristiwa tutur tersebut sama artinya dengan kata malala dalam bahasa Minangkabau. Kata dasar darikata malala ini adalah lala. Lala 'keluyur' ditambahkan dengan awalan mamenjadi malala ngeluyur; tak tentu tujuan' Kamus Umum Bahasa Minangkabau Indonesia (2002:340), kata malelong ini adalah bentuk baru yang dikreasikan oleh komunitas banci. Selain itu, arti darijargon tinta yaitu 'tidak'. Petuturan tersebut terjadi disaat penutur $(\mathrm{X})$ dan mitra tutur (Y) sedang melakukan perawatan tubuh disalah satu pusat kecantikan di kota Padang, dimana penutur (X) dan mitra tutur (Y) sering melakukan perawatan di tempat tersebut. Mitra tutur (Y) terlihat malas dan tidak bersemangat saat ditawarkan untuk pergi bermain oleh penutur (X) setelah selesai melakukan perawatan tersebut. Masyarakat di luar komunitas banci mengenal kata tinta ini adalah 'barang cair yang berwarna (hitam, merah, dsb) untuk menulis, atau dawat Kamus Besar Bahasa Indonesia selanjutnya disingkat KBBI (1990:951). Dalam peristiwa tutut tersebut kata tinta mengalami perubahan makna dari makna yang sebenarnya.

Selain itu ada juga penelitian 
yang secara khusus membahas tentang bahasa waria pernah dilakukan oleh Dede Oetomo pada tahun 1988. Dede Oetomo adalah seorang dosen yang juga berprofesi sebagai aktivis komunitas homoseksual gaya Nusantara di Surabaya. Melalui makalah seminarnya yang berjudul "Bahasa Rahasia Waria dan Gay di Surabaya", Oetomo menjelaskan bahwa pada dasarnya ada dua pola pembentukan bahasa waria dan gay di Surabaya. Pola pembentukan yang pertama adalah struktur pembentukan kaidah perubahan bunyi yang produktif dan teramalkan. Pola pembentukan kedua adalah penciptaan istilah baru atau pemberian makna istilah umum yang sudah ada. Adapun perbedaan antara penelitian ini dengan penelitian Oetomo yakni tempat penelitian Oetomo di Surabaya

Sementara penelitian ini dilakukan di Yogyakarta. Perbedaan tempat penelitian ini menyebabkan perbedaan kosakata bahasa waria yang digunakan karena adanya perbedaan dalam pola pembentukannya. Sebagai contoh, di Surabaya kata banci berubah menjadi siban karena adanya pemenggalan silabe pertama kemudian diberi awalan si- sedangkan di Yogyakarta kata banci berubah menjadi bencong karena adanya modifikasi bunyi [a] menjadi [e] ditambah akhiran-ong. Selain perbedaan tersebut, penelitian ini lebih menekankan fokus pada kelompok waria.

Sementara itu, Sari (2000) dalam penelitiannya yang berjudul "Slang waria dan Gay di Kotamadya Yogyakarta" juga membahas bahasa waria di Yogyakarta. Dalam skripsi tersebut, Sari tidak hanya membahas bahasa waria tetapi juga bahasa komunitas gay yang digunakan di wilayah Kotamadya Yogyakarta. Data yang diperoleh Sari berupa data tuturan dan data tulisan. Meskipun secara sekilas penelitian yang dilakukan Sari hampir sama dengan penelitian ini, data penelitian yang diambil merupakan data tuturan 14 tahun yang lalu sehingga diasumsikan data telah mengalami perubahan. Sebagai contoh, dalam data penelitian ini ditemukan kata henpina yang merujuk pada kata handphone yang belum populer pada masa itu. Selain itu, pada data penelitian ini ditemukan variasi kata rumpi yang sudah digunakan dari dulu. Kata rumpi dalam data penelitian ini memiliki variasi lain seperti rumput dan rumpita. Kata lain yang juga mengalami perubahan yakni kata bintil yang berubah menjadi binan. Kata ini merujuk pada kata banci atau kelompok gay. Selain perbedaan data tersebut, penelitian ini hanya berfokus pada slang waria. Penelitian sebelumnya belum membahas proses pembentukan slang waria Yogyakarta secara terperinci. Cakupan wilayah penelitian ini juga lebih luas yang meliputi wilayah Kabupaten Sleman dan Kotamadya Yogyakarta.

\section{METODE PENELITIAN}

Dalam penelitian ini digunakan pendekatan kualitatif, sedangkan Metode penelitian yang digunakan adalah deskriptif. Pendekatan kualitatif adalah konsepkonsep dan keterangan yang berbentuk uraian dalam mengungkap masalah. Penelitian kualitatif adalah sebagai prosedur penelitian yang menghasilkan data. Karena 
permasalahan yang dibawa oleh peneliti masih bersifat sementara, maka teori yang digunakan dalam penyusunan proposal penelitian kualitatif juga bersifat sementara. Dalam kaitannya dengan teori, kalau penelitian kuantitatif bersifat menguji hipotesis atau teori, sedangkan dalam penelitian kualitatif bersifat menemukan teori. Oleh karena itu dapat disimpulkan bahwa penelitian kualitatif jauh lebih sulit dari penelitian kuantitatif, karena penelitian kualitatif harus berbekal teori yang luas sehingga mampu menjadi "human instrumen" yang baik.Teknik pengumpulan data dokumentasi adalah suatu cara untuk mengumpulkan data-data yang diperlukan dalam penelitian ini. Sehubungan dengan penelitian ini data diperoleh dari sumber data yang dilakukan dengan cara.Teknik dasar : Teknik Sadap.teknik simak libat cakap,teknik rekam,teknik catat Analisis data merupakan upaya menelaah atau menguraikan masalah yang terkandung dalam data. Setelah data terkumpul, tahap selanjutnya adalah menganalisis data sesuai dengan tujuan yang akandibahas. Data tulis yang sudah terkumpul dari rekaman pada waria kemudian dipilah sesuai dengan data yang diperlukan. Metode analisis data yang digunakan pada penelitian ini adalah metode agih. Metode agih adalah metode analisis data yang alat penentunya justru bagian dari bahasa itu. Teknik dasartek $\vec{n} \hat{k}$ bagi unsur langsung.

\section{HASIL PENELITIAN DAN PEMBAHASAN}

Pada bagian ini dikemukakan hasil analisisdata tentang penggunaan bahasa slang waria dalam kajian pragmatik dalam interaksi sesama waria.

Bahwa objek kajiannya didasarkan pada bahasa wariayang prosesnya menggunakan teori distribusional analisis, yakni.

$\begin{array}{lll}\text { - } & \text { Penggantian } & \text { (Subtitusi) } \\ \text { - } & \text { Penambahan } & \\ \text { - } & \text { Penyisipan } & \text { (Interupsi) } \\ \text { - } & \text { Penghilangan } & \text { (Delisi) } \\ \text { - } & \text { Pengulangan } & \text { (Repetisi) } \\ \text { - } & \text { Perubahan total } & \text { (Parafrasa) } \\ \text { Untuk lebih jelasnya dapat dipaparkan } \\ \text { berikut. }\end{array}$

\section{Penggantian ( Subtitusi )}

Teknik penggantian (Subtitusi) adalah teknik analisis data dengan menyelidiki kepararelan atan kesejajaran distribusi satuan lingual. Untuk lebih jelas dapat dilihat pada contoh berikut.

(1) Eke sih gak tentu kadang-kadang pakai bahasa waria,bahasa jawa gitu

(Aku sih tidak tentu kadang-kadang pakai bahasa

$$
\begin{aligned}
& \text { waria,bahasa jawa } \\
& \text { gitu) }
\end{aligned}
$$

Pada data (1) ditemukan adanya kosakata waria Eke jika dilihat dari kosakata umum berartiaku hal itu dikarenakan, adanya penggantian unsurtertentu dalam satuan lingual yang bersangkutan dengan "unsur" tertentu yang lain di luar satuan lingual.

kata Eke pada kutipan data (1) ditemukan adanya penggantian unsurunsur pada kosakata dari bahasa waria kebahasa Indonesia secara umum misal pada kata eke menjadi aku. Proses penggantian dimulai pada SK1 ada perubahan vokal [a] [e], penggantian tersebut didasarkan pada penggunaan bahasa waria yang 
cenderung mengubah bunyi vokal [e] pada SK1 menjadi bunyi vokal [a]. Sedangkan SK2 ada perubahan vokal [e] $[\mathbf{u}]$, penggantian tersebut didasarkan pada penggunaan bahasa waria yang cenderung mengubah bunyi vokal [e] pada SK2 menjadi bunyi vokal $[\mathrm{u}]$.

proses perumusannya SK1 : [e] [a],

SK2 : [a][u]

(2)Yaa.. eke kan cintong terhadap kehidupan saya,mau gak mau harus menggunakan bahasa waria, kan saya termasuk anggota komunitas

(Yaa..aku kan cinta terhadap kehidupan saya,mau gak mau harus menggunakan bahasa waria, kan saya termasuk anggota komunitas)

Pada data (2) ditemukan adanya kosakata waria cintong yang jika dilihat dari kosakata umum berarti cinta hal itu dikarenakan adanya penggantian unsurtertentu dalam satuan lingual yang bersangkutan dengan "unsur" tertentu yang lain di luar satuan lingual.

Kata cintong Pada kutipan data (2) ditemukan adanya penggantian unsurunsur pada kosakata dari bahasa waria kebahasa Indonesia secara umum misal pada kata cintong menjadi cinta. proses penggantian dimulai dari SK2 ada perubahan vokal [ong] [a]. Penggantian tersebut didasarkan pada penggunaan bahasa waria yang cenderung pada ciri khas bahasa waria yang mengubah huruf vokal pada SK2 diganti dengan [ong]

proses perumusannya SK2 : [ong] [a]

Jika pada data (2) ditemukan proses penggantian pada SK2 namun berbeda dengan data (3) ditemukan proses penggantian pada SK1 dan SK2 pada data (3) contohnya akan dijelaskan sebagai berikut.

\section{Penambahan}

Adalah sebuah proses terjadinya pembentukan kata yang digunakan dalam kalimat pembanding. Untuk lebih jelasnya dapat dilihat dari contoh berikut.

(6) Hahahaha itu pasti lah mas, malah ada yang bilang gini ehh mbaknya cantik, rambutan maksudnya rambut agak pendek dll..lah maspokoknya mereka jahara banget.

(Hahahaha itu pasti lah mas, malah ada yang bilang gini "ehh mbaknya cantik,rambut agakpendek dll..lah mas pokoknya mereka jahat banget.)

Pada data (6) ditemukan adanya penambahan pada beberapa fonem dibelakang suku kata, dari bahasa waria kebahasa Indonesia secara umum misal pada kata rambutan menjadi rambut, proses penggantian dimulai pada SK2. Ada penambahan sufiksdibelakang suku kata [an], penambahan tersebut didasarkan pada penggunaan bahasa waria yang cenderung berubah- ubah seperti cara pegambilan kata secara asal tanpa memperhatikan kaidah pembentukan kata, lalu menambahkan sufiks -an. proses perumusannya SK2 : rambut rambut[an].

(7) Eke sih jam 22.00 mangkal, pulang-pulang sudah pagi, setelah itu eke tidure, jam 09.00 aneke blumbung bangunan

(Aku sih jam 22.00 mangkal, pulang-pulang sudah pagi, 
setelah itu aku tidur, jam 09.00 an aku belum bangun)

Pada data (7) ditemukan adanya penambahan pada beberapa fonem dibelakang suku kata, dari bahasa waria kebahasa Indonesia secara umum misal pada kata bangunan menjadi bangun, proses penggantian dimulai pada SK2. Ada penambahan fonem dibelakang suku kata [an],penambahan tersebut didasarkan pada penggunaan bahasa waria yang cenderung berubah-ubah seperti cara pegambilan kata secara asal tanpa memperhatikan kaidah pembentukan kata, lalu menambahkan sufiks $\underset{\rightarrow}{\rightarrow} \underset{\rightarrow}{\rightarrow}$.

proses perumusannya SK2 : bangun bangun [an].

\section{Penyisipan (Interupsi)}

Adalah proses penyisipan bunyi atau huruf kedalam kata, terutama kata serapan tanpa mengubah arti untuk penyesuaian dengan pola fonoligis bahasa meminjam. Untuk lebih jelasnya dapat dilihat dari contoh berikut.

(10) Kalau eke sihh sering jatuh cinta gitu, malah dulu eke pernah pacaran 5 tahun, tapi akhirnya yaa diputusin,padahal eke tipe orangsetia (setrika)

(Kalau aku sihh sering jatuh cinta gitu, malah dulu aku pernah pacaran 5 tahun, tapi akhirnya yaa diputusin,padahal aku tipe orang setia)

Pada data (10) ditemukan penyisipan "unsur" tertentu di antara unsur-unsur lingual yang ada. Misalnya, satuan lingual data ABCD dengan menggunakan teknik sisip akan didapat: ABCID, ABICD, atau AIBCD $(I=$ interuptor atau unsur penyisip).

Pada kutipan data (10) ditemukan adanya penyisipan bunyi atau huruf pada kosakata dari bahasa waria kebahasa Indonesia secara umum misal pada kata setrika menjadi setia. Proses penyisipan dimulai pada SKT. Ada penyisipan huruf $[\mathbf{r}]+[\mathbf{k}]$, penyisipan didasarkan pada penggunaan bahasa waria yang mengubah kosakata dengan cara menyisipkan huruf sesudah konsonan awal pada suku kata tertentu, sehingga kata menjadi dua kali lipat lebih panjang.

proses perumusan SKT : set

$[\mathbf{r}]$

i $\quad\left[\begin{array}{ll}k & a\end{array}\right.$

(11) W : Eke juga waria yang $\rightarrow$ soprano ( sopan) loocin gak seneng ngerebut pacar orang

(Aku juga waria yang sopan loo cin gak seneng ngerebut pacar orang)

Pada data (11) ditemukan penyisipan "unsur" tertentu di antara unsur-unsur lingual yang ada.

Pada kutipan data (11) ditemukan adanya penyisipan bunyi atau huruf pada kosakata dari bahasa waria kebahasa Indonesia secara umum misal pada kata soprano menjadi sopan. Proses penyisipan dimulai pada SKT. Ada penyisipan huruf [r]. Sedangkan SK2 Ada penambahan fonem [o], penyisipan didasarkan pada penggunaan bahasa waria yang mengubah kosakata dengan cara menyisipkan huruf sesudah konsonan awal pada suku kata tertentu, sehingga kata menjadi dua kali lipat lebih panjang. 
Proses perumusan SKT $\rightarrow$ sop $\rightarrow[\mathbf{r}]$ a

(12) Yaa kalau waria gini cuma sukria (suka) aja mas gak sampek cintong banget, namanya juga waria mas cuma untuk cari kepuasan.

(Yaa kalau waria gini cuma suka aja mas gak sampek cintabanget, namanya juga waria mas cuma untuk cari kepuasan)

Pada data (12) ditemukan penyisipan "unsur" tertentu di antara unsur-unsur lingual yang ada.

Pada kutipan data (12) ditemukan adanya penyisipanbunyi atau huruf pada kosakata dari bahasa waria kebahasa Indonesia secara umum misal pada katasukria menjadi suka. Proses penyisipan dimulai padaSKT.

Ada penyisipan huruf [ri], penyisipandidasarkan pada penggunaan bahtesa ria yang mengubah kosakata dengan cara menyisipkan hurufsesudah konsonan awal pada suku kata tertentu, sehingga kata menjadi dua kali lipat lebih panjang. proses perumusan SKT : suk [ri] a

\section{Penghilang \\ (Delisi) $\quad+$ penambahan}

Teknik lesap adalah teks analisis data ( melepaskan, menghilangkan, menghapus ) unsur satuan lingual. Untuk lebih jelasnya dapat dilihat dari contoh berikut.

(13) Hahahaha itu pasti lah mas, malah ada yang bilang gini "ehh mbaknya cantik,rambutan maksudnya rambut agak pendek dll..lah maspokoknya mereka jahara banget

(Hahahaha itu pasti lah mas, $\mathrm{n}[\mathbf{o}]$ malah ada yang bilang gini "ehh mbaknya cantik,rambut agakpendek dll..lah mas pokoknya mereka jahat banget)

Pada kutipan data (13) ditemukan adanya penghilang dan penambahan bunyi atau huruf pada kosakata,dikarenakan terdapat penghilangan salah satu fonem [t] berganti dengan fonem [r] dan juga ada penambahan fonem [a], dari bahasa waria kebahasa Indonesia secara umum misal pada kata jahara menjadi jahat. Proses penghilangan dan penambahan dimulai pada SKT. Ada penghilangan huruf $[\mathbf{t}][\mathbf{r}]$. Sedangkan SK2 proses penambahan [a]. Prosesperumusannya

SKT : [t] [r], SK2 : [a]

\section{Pengulangan (Repetisi)}

Adalah proses pengulangan kata atau unsur kata baik pengulangan utuh atau sebagian. Untuk lebih jelasnya dapat dilihat pada contoh berikut.

(14) Pernah deh.. kapan gitu eke lupia, eke pernah ditawari main sex gitu, tapi saya menolaknya, pakek imingiming diajak jali-jali gitu hahahaha..

( Pernah deh.. kapan gitu aku lupa, aku pernah ditawari main sex gitu, tapi saya menolaknya, pakek iming-iming diajak jalan-jalan gitu hahahaha)

Pada kutipan data (14) ditemukan adanya pengulangan. Suku kata awal tidak mengalami perubahan sedangan suku kata kedua ada perubahan vokal (i menjadi an), proses pengulangan didasarkan pada penggunaan bahasa waria yang cenderung mengubah- 
ubah kata seperti pemotongan kata awal lalu diganti dengan kata lain secara manasuka atau sembarang. Rumusan kata jali-jali jalan-jalan

$$
\text { SK2 : (i)(an) }
$$

\section{Perubahan total (parafrasa)}

Adalah perubahan yang dilakukan secara menyeluruh atau utuh yang mengakibatkan berubahnya makna secara keseluruhan. Untuk lebih jelasnya bisa dilihat pada beberapa contoh berikut.

(15) Eke Maluku cin gak duwe duta, mangkane aktivitas padat masio pengawean ngamen terus

(Aku malu cin tidak punya uang, mangkanya aktivitas padat meskipun pekerjaan ngamen terus)

(16) Hahahahaha eke sih yaa sutra

( Hahahahaha aku sih yaa terserah)

Teknik ubah ujud mengakibatkan berubahnya wujud salah satu atau beberapa unsur satuan lingual yang bersangkutan dari analisis pada perubahan cenderung tidak beraturan sehingga tidak memiliki rumusan, dapat dilihat pada contoh diatas.

\section{SIMPULAN}

Berdasarkan hasil penelitian, penggunaan bahasa slang pada komunitas waria di kota Surabaya (kajian linguistik), merupakan varian bahasa. Bahasa waria hanya digunakan oleh kelompok waria saja maupun orang-orang yang bergaul dan akrab dengan waria. Ciri khas bahasa waria memiliki penyimpangan makna. Bahasa waria dapat dinyatakan sebagai hasil modifikasi atau turunan dari bahasa Indonesia maupun bahasa daerah. Penggunaan kosakata bahasa waria masih terbatas dan diperkirakanakan berkembang dan terus bertambah pata masa yang akan datang sesuai dengan kebutuhan yang diinginkan oleh kaum waria dalam menyampaikan sesuatu. Jumlah penggunaan kosakata tersebut masih minim dan belum dapat mewakili sepenuhnya dalam mengungkapkan semua ide, gagasan, perasaan, dan sebagainya kepada orang lain.Kalimatkalimat dalam bahasa waria dinyatakan, bahwa kalimat yang digunakan dalam percakapan tidak terikat pada situasi resmi, melainkan dalam situasi santai atau rileks. Struktur kalimat bahasa waria tidak terikat atau berdasarkan pola sintaksis bahasa Indonesia sepertipada subjek, predikat, objek, dan keterangan.

\section{SARAN}

Berdasarkan hasil penelitian mengenai penggunaan bahasa slang pada komunitas waria di kota surabaya, peneliti memberikan saran yang bermanfaat dan dapat menambah pengetahuan bagi pembaca dalam mempelajari ilmu kebahasaan, yakni :

1. Bagi pembaca, dapat menambah wawasan mengenai penggunaan bahasa slang yang digunakan oleh komunitas waria.

2. Untuk peneliti lain, dapat menjadikan acuan dalam menganalisis bagaimana perumusan pada kosakata bahasa slang.

\section{DAFTAR PUSTAKA}

Anonim. 2010. Transgender

(http://id.wikipedia.org/wiki/transge

nder

Budi. 2009. Fenomena 
Transgender dan HukumOperasi

Chaer, Abdul dan Agustina. 1995. Sosiolinguistik Suatu

Pengantar. Jakarta.: Rineka Cipta

Chaer, Abdul. 2003. Linguistik Umum. Jakarta: Rineka Cipta.

Departemen Pendidikan Nasional. 2001. Kamus Besar Bahasa Indonesia. Jakarta: Balai Pustaka.

Jumiati, Irani. 2003. 'Jargon bahasa waria suatu kajian
pragmatic',.
Universitas
Muhammaddiyah makasar.

Keraf, Gorys. 1991. Tatabahasa Rujukan Bahasa Indonesia. Jakarta: Gramedia.

Komariah, Iis. 2001. 'Jargon yang digunakan komunitas banci salon di kota padang, sumatera barat". Skripsi. Universitas Andalas.

Kridalaksana, Harimurti. 1984. Kamus Linguistik. Jakarta: Gramedia. Kridalaksana, Harimurti. 1985. Fungsi dan Sikap Bahasa. Ende: Nusa Indah.

Lubis, Hamid Hasan. Medan.1990. Jenggala Bahasa Indonesia.
Bandung: Angkasa.

Moleong, Lexy. 1989. Metode Penelitian Kualitatif. Bandung: Rosdakarya.

Mustakim. 1992. Membina

Kemampuan Berbahasa. Jakarta:

Gramedia Pustaka

Ningsih, Sri dkk. 2007. Bahasa

Indonesia Untuk Mahasiswa.

Yogyakarta: Andi.

Pateda, M. 1985. Semantik Leksikal.

Ende Flores:Nusa Indah.

Pateda, Mansoer.

1987.

Sosiolinguitik. Bandung:

Angkasa Bandung.

Pamungkas. 1972. Pedoman Umum

Ejaan Bahasa Indonesia yang Disempurnakan EYD. Surabaya: Giri Surya.

Samsuri. $1987 . \quad$ Analisa

Bahasa:Memahami Bahasa

Secara

Ilmiah.Jakarta: Erlangga. Sudaryanto. 1993. Metode dan aneka teknik analisisbahasa: pengantar penelitian wahana

kebudayaan secara linguistik.

Usman, Abdul Kadir. 2002. Kamus

Umum

Bahasa

Minangkabau Indonesia.

Padang:Anggrek Media. 